\title{
Impact of Corporate Governance on the Performance of Commercial Banks in Zimbabwe
}

\author{
Progress Shungu \\ Department of Finance, NUST, Zimbabwe \\ Email: pshungu302@gmail.com
}

Hlanganipai Ngirande

Department of Business Management. University of Limpopo, Private Bag 1106. Sovenga, 2707. South Africa.

Email: hlanganipai@gmail.com

\section{Godfrey Ndlovu}

Hlanganipai Ngirande, Department of Business Management, University of Limpopo (Turfloop Campus) Private Bag 1106. Sovenga, 2707, South Africa

Doi:10.5901/mjss.2014.v5n15p93

\begin{abstract}
The background of corporate governance dates back to the 19th Century when state corporation laws enhanced the rights of corporate boards without unanimous consent of shareholders. The concept propounds that corporation should have a good board structure in order to enhance performance. It is firmly rooted on the assumption that good corporate governance practices enhance corporate performance. However, there is no consensus on the impact of corporate governance on performance. The increasing role of the financial sector, on both economic development and poverty alleviation, has seen the concept being applied more on the financial sector than before; this has been further aggravated by world financial crisis, and its consequences. In this regard, Zimbabwe is no exception, during the period 2003-2009 the Zimbabwe witnessed unprecedented failure in the financial sector rooted from a number of issues; but chief among them has been cited as poor corporate governance practices. However, there have been mixed feelings on the extent to which bank performance can be attributed to corporate governance. The paper presents the findings of the study that was conducted to investigate the impact of corporate governance on the performance of commercial banks in Zimbabwe. Using data gathered from 2009-2012, for a sample of five commercial banks, it applies multi-regression model, to assess the causal relationship between corporate governance measures (board size, board composition, internal board committees and board diversity) and bank performance. The results indicate unidirectional causal relationship from corporate governance to bank performance. In addition, there a positive relationship between board composition, board diversity and commercial bank performance, although a negative relationship appears between board size, board committees and bank performance. Therefore, in order to improve performance in commercial banks good corporate governance practices must implemented, this includes improving board structures, disclosure, and fiduciary duties of directors. On the hand the Reserve Bank of Zimbabwe should ensure or put in place robust supervisory and regulatory policies; the development and implementation of a national corporate governance code is long overdue.
\end{abstract}

Keywords: Impact, Corporate governance, commercial bank, Performance

\section{Introduction to and Background to the Study}

The background of corporate governance dates back to the $19^{\text {th }}$ Century when state corporation laws enhanced the rights of corporate boards without unanimous consent of shareholders. They did it in exchange for statutory benefits such as appraisal rights in order to make corporate governance more efficient. The early debates came up after the increase of agency problem, which emanated from separation of ownership and control created in the case of Salomon v Salomon, (1897). Recently corporate governance becomes a hot topic among a wide spectrum of people, government, industry operations, directors, investors, shareholders, academics and international organisations to least but a few. Today's world has seen that organisation transparency, financial disclosure, independency, board size, board composition, board committees, board diversity and among other is the cornerstone of good governance practices. These variables are in the main agenda of most meetings and conferences worldwide including the World Bank, International Monetary Fund (IMF) 
and Organisation of Economic Co-operation and Development (OECD) (Inyanga, 2009).

Recently researchers have managed to come up with many definitions of corporate governance. Strine (2010) pointed out that corporate governance is about putting in place the structure, processes and mechanisms that insure that the firm is directed and managed in a way that enhances long-term shareholder value through accountability of manager, which will then enhancing firm performance. OECD (1999) defined it as the system by which business corporations are directed and controlled in favour all the stakeholders. Currently financial sectors have seen the importance of having good corporate governance practices (Kolk \& Pinkse, 2010). IFC (2004) examined the benefits of having good Corporate Governance at different levels. At the company level, well-governed companies tend to have better and cheaper access to capital, and tend to outperform their poorly governed peers over the long-term, on the other hand corporate governance reduce financial crisis (IFC, 2004).

Currently many country leaders all over the world has increased concern over corporate governance due to the increase of reported cases of frauds, inside trading, agency conflicts among other corporations saga (Enobakhare, 2010). Corporate failure has recently witnessed in both developed and developing countries with the reported cases of the East Asia crises of 1997/98, the collapse of Enron in 2001 and WorldCom in 2002, (Inyang, 2009) and the just ended global financial crisis of 2007/8. The crises emanated from the poor governance practices from the financial sector (the mortgage market). Since mortgage market was the mother of the crisis, this has triggered the world leaders to enact some laws, which increase banks governance. This is supported by Ahmad (2006) who argued that a sound banking system requires appropriate infrastructure to support efficient conduct of banking business operating environment, governance and regulatory framework at domestic as well as international levels in order to reduce bank crisis. The World Bank is helping currently many economies to undertaking the banking sector reformation and restructuring. This exercise will easy, reduce or eliminate some fatal global macroeconomic troubles which have emanated from poor governance of large financial and non-financial institutions (Zaharia, Tudorescu \& Aharia, 2010).

In most recently, researchers worldwide have grown interest on corporate governance and corporate performance of commercial banks as witnessed by an explosion research on corporate governance (Adams, 2012; Adams, Hermalin \& Weisbach, 2008). Commercial banks should show good corporate governance since they play a critical role in the corporate governance of other firms (Franks \& Mayer, 2001; Santos \& Rumble, 2006), as creditors or equity holders of firms. In this regard, commercial banks must be transparent, accountable, trustworthy and responsible to the public. Zimbabwean commercial banks like any other banks in the world are facing corporate governance challenges. The commercial banks have previously witnessed a phenomenal growth after the economic deregulation in 1991. The economic turbulences and political meltdown that have cornered the country in year 2000, 2004 and 2008 has created a new challenging environment. By the mid of 2012, the country has experienced intermittent corporate governance turmoil which has caused the closure of Royal bank, Genesis bank, and placement of Interfin bank under recuperative curatorship by the central bank (RBZ, 2012).

The study investigates the impact of corporate governance on commercial banks, in order to assess the significance of corporate governance in the commercial banks of Zimbabwe. This would be done in line with the empirical studies carried out by Bhagat and Bolton (2008) in the US, who found that corporate governance, has an impact on firm performance during the 1990s. On the policy domain, corporate governance proponents have prominently cited this study as evidence that good governance has a positive impact on corporate performance. However, Laeven, and Levine (2009 argued that corporate governance might not capture the true relationship with corporate performance unless other specific aspects of governance are controlled. However, relatively limited attention has been done on corporate governance of commercial banks in Zimbabwe of which commercial banks are the cornerstone of financial system in any economy as advocated by (Adams \& Mehran, 2005; Caprio et al., 2007). The researchers increased an eager over this gray area of finding out if corporate governance has an impact on commercial banks performance in Zimbabwe after the introduction of multi-currency in 2009. The research is in line with other studies done in countries like Nigeria, Italy among others.

By considering the above debate, the researchers are confident enough to argue that Zimbabwe neglect of core issues of corporate governance, which has supposed by poor corporate governance practices experienced in country's commercial banks ever since 2004. In relation to this the aim of this study, is to explore the impact of corporate governance on commercial banks' performance in Zimbabwe. By taking it a step further, board structure was used as the proxy for corporate governance since directors are the one who influences the bank management and operations activities. The researchers believed that this topic has created a gray area among stakeholders by leaving them with mountain of questions and a hill of answers. The researchers decided to solve the quagmire questions by making a deep research and analysis on the major key drivers of good corporate governance on the Zimbabwean commercial banks sector during the period 2009 to 2012. 
The paper also assumed that a good corporate governance practice will enhances commercial banks performance. Corporate governance would be measured by board structure (board size, board composition, internal board committees, and board diversity) and commercial bank performance would be measured by return on equity ratio (ROE).

\section{Literature Review}

According to (Fernando, 2009) corporate governance concept has gone further as a subject of matter, an objective, or a regime followed for the good of shareholders, employees, customers, bankers and indeed for the reputation and standing of a nation and its economy. OECD, (1999) extent the concept of corporate governance as the system by which business corporations directed and controlled for the better of stakeholders and shareholders.

Currently, researchers worldwide has faced some challenges on try to analyses the effect of corporate governance on corporate performance. A challenge was discovered to be the ideal measure of corporate governance, as there is no universally accepted measure of corporate governance (Calabrese, Costa, Menichini, Rosati, \& Sanfelice, 2013). Yakasai (2001) argued that board structure could be an ideal measure of corporate governance. However, (Chiorazzo et al., 2008) has used corporate ownership and control as the measure of corporate governance for big and non-financial corporations. According to Ramano et al. (2012), corporate governance should use any variable, which has a direct impact on corporation performance. After measuring this concept using board structure Boone, Casares Field Karpoffa and Raheja (2007) confront that good corporate governance practices seem to enhance bank performance since it effect the reputation on the bank in the overall market.

\subsection{Importance and Key Characteristics of Corporate Governance}

Corporate governance has taken a stronger foothold in developed countries when compared to emerging economies. Kolk and Pinkse (2010) asserts that good corporate governance has many benefits to the organization. The importance of corporate governance tends to be different with the level of organizational governance (IFC, 2004). Calabrese et al. (2013) argued that company level, well-governed companies tend to have better and cheaper access to capital, and tend to outperform their poorly governed peers over the long-term. Companies that insist upon the highest standards of governance reduce many of the risks inherent to an investment in a company (IFC, 2004). In a similar view, Barth, Caprio and Levine (2006) pointed out that good corporate governance can reduce the risk of financial crisis, which can have devastating social and economic costs. Finally, good corporate governance can lead to better relationship with all stakeholders and thus improve labour relations as well as the climate for improving social aspects such as environmental protection (Enobakhane, 2010). However, James and Arthur (2003) view this as unreasonable.

The directors are the key characteristic of good corporate governance mechanism (Blair, 1995) and are regarded as the officers of the company by the company law (Coleman, 2008). Based on the literature board structure (board size, board composition, board committees, and board diversity) could be used as a proxy for measuring corporate governance practices in firms (Enobakhane, 2010) since directors are the once who control the company. Board structure refers to how the organisation is structured in terms of the board of directors (Vaithilingam, 2006). Ogbechie and Koufopoulos (2009) argued that a board structure is an integral part of the corporation as it plays a key role in the wellbeing of the firm.

\subsubsection{Board Size}

According to Enobakhane, (2010) board size is the total number of directors that an organisation has in its board structure. This is calculated, as the total minimum number of directors (at least five) needed by the central bank over the total number of directors in the board of directors at the end of the annual financial year. It goes without doubt that the number and quality of directors in a company has an effect on how the board functions, hence its company performance. Empirical research has shown that best board size influencing the firm performance inconclusive. The possibility of a large board size has the likelihood of having more knowledge and skills at their disposal, which will enhance performance (Williams, 2002). Ramano et al. (2012) argue that when boards grow, they become less likely to function effectively (Jensen, 1993) may create a diminished sense of individual responsibility and might be more involved in bureaucratic problems. In the most recently empirical researches worldwide with reference to banking sector for different countries, results find no significant relationship between board size measure and banks performance (Busta, 2007; Zulkafli and Samad, 2007; Shelash Al-Hawary, 2011). Research has shown that bank holdings structures and activities may make a larger board more desirable, increases in board size due to additions of directors with subsidiary directorships may add 
value Romano et al. (2012). Conversely, (Cornett et al., 2009) argued that larger boards are positively associated with corporate performance However, some other studies found that improving board size has a negative effects on bank performance after calculated using different regression model, other methods and indicators (Staikouras et al., 2007; Trabelsi, 2010).

\subsubsection{Board Composition}

According to Enobakhare (2010) board composition is the total number of directors brought from outside the company to sit on the board divided by the board size in a given period. It was chosen as the proxy for corporate governance because literature has found that it has a link with good governance. Board composition is a debated corporate governance issue since it could influence board deliberations and the capability to control top management decisions and results. Although there is not an optimal formula (Vance, 1978), board independence has become a relevant issue in the corporate governance agenda. Actually, non-executive and independent directors considered one of the most important mechanisms for ensuring corporate accountability and firm growth (Ramano et al, 2012). Conversely, De Andres and Vallelado (2008) assets that an excessive proportion of nonexecutive directors could damage the advisory role of boards since executive directors facilitate the transfer of information between directors and management and give information and knowledge that outside directors would find difficult to gather.

Empirical research affirmed that firms committing financial reporting fraud are more likely to have a poor board of directors dominated by insiders (Farber, 2005; Romano et al., 2012). Many countries have strengthened recommendations on board composition and independence in the companies (Huse, 2005). In Uganda, both the regulatory framework and market best practices place more emphasis on board independence in the bank's management (Busch, 2008).

\subsubsection{Board Committees}

Board committees are internal regulatory and supervision board chaired by an external director which over sees the effective operation and acts of the board of directors (RBZ, 2004). They are calculated as the total minimum number of internal committees, which the central bank and international corporate governance codes needs (at least three committees-audits \& risk committee, remuneration committee and main board management committee) for a bank over the total number of committees, the commercial bank has at the end of the trading period. It chosen as the proxy for corporate governance since it is in line with the literature. Romano et al. (2012) argued that board committees are an important corporate governance tools which monitor corporate activities and protection of shareholder value. Many countries requires all listed companies as well as all banks to have an internal control and risk (audit) committee, remuneration committee and nomination committee; among other committees (Bank of Italy, 2008). Bussoli (2013) cited that the board committees is the yardsticks for better functioning of banks, as the number of board committees is statistically significant to banks performance.

Audit committee and Risk management committee - review the financial conditions of the banking institution, internal controls, bank performance and the findings of the internal auditors will be reported to the board with some recommended (King II, 2006). It also assists the board to discharging its duty of review the quality of the loan portfolio Najjar (2011). The committee should imply a strong independence and transparency from the board and clearly communicate to all employees the risk strategy and risk appetite or tolerance of the company (Enobakhare, 2010). Prior researches have principally investigated audit and loan review committee in terms of type, gender, non-executive and occupation of directors (Uzun et al., 2004; Lin et al, 2008).

Asset and liability management committee (ALCO)- this is the most appropriate strategy for today's banking institution in terms of the mix of assets and liabilities given its expectations of the future and the potential consequences of interest rate movements, liquidity constraints and foreign exchange exposure and capital adequacy (Romano and Guerrini, 2012). ALCO committee is required to better perform its role, as it requires more discussions and assures more skills, backgrounds and competences (Alkdai \& Hanefak, 2012). This cohesiveness can increase ALCO committee vigilance over the board decisions and curtail potential managerial opportunism.

Nomination and Remuneration committee- is a relevant and effective tool to align managers and shareholders' interests, mitigating agency costs and providing a link between managerial actions and performance (Romano et al, 2012). This committee should constitute only non-executive directors, of whom the majority should be independent, and chaired by the board chairperson (Grove et al, 2011). According to Sierra et al. (2006) with reference to US, bank holding companies reported that nomination committee is one of the most important committee, which appoint in new committed 
directors and fire uncommitted.

\subsubsection{Board Diversity}

Board diversity is the mixture of men and women, people from different age brackets, people with different ethnic groups and racial backgrounds (Enobakhare, 2010). Currently board diversity is a highly debatable corporate governance topic. The topic put more emphasis on, gender diversity, i.e. the inclusion of women on corporate boards of directors, considered as an instrument to improve board variety and thus discussions (Anastasopoulos et al., 2002). This is calculated as the total number of women in the board over the board size in a given over a period. Its' believed that board diversity affects corporate governance either a direct or an indirect effect on the firm. Though board diversity might be a constraint according to Goodstein, nevertheless it goes without doubt that for boards to be effective there is need for diverse perspective (Ogbechie \& Koufopoulos, 2009). As reported by Dutta and Bose, (2006) the presence of women on boards of directors is limited, even if the literature reveals a slow but steady rise in the female presence on corporate boards throughout the world. With reference to the relationship between gender diversity and firm performance, the few existing empirical studies show contrasting results. Considering the US context, Zahra and Stanton (1988) find no statistically significant relationship between gender diversity and firm performance. Dutta and Bose, 2006) reported a statistically significant positive relationships between both the presence and the percentage of women on the board of directors and market value added (MVA) and firm value. Conversely, Shrader et al. (1997) show a negative relationship between the percentage of female board members and firm performance.

\subsection{Relationships between Corporate Governance and Corporate Performance, directors' corporate governance (disclosure) and performance}

Several studies came up with inconclusive results when it comes to the relationships between corporate governance and corporate performance. Adams and Ferreira (2009) found no relationship between having independent directors and firm performance; however, Kaplan and Minton (1995) find that poor corporate performance is associated with the appointment of an outside director. There is no relationship between performance and governance if shareholders given few shares by the company as witnessed by (Kang \& Shivdasani, 1995) who argued that equity ownership by management if small is the same as the agency costs. When management are given shares of the company, they tend to direct the operation in the interest of shareholders of wealth maximisation the same as before given those small shares (Denis \& McConnell, 2003).

After using ordinary least squares regression, Murali \& Welch (1989) examined the forces that may affect ownership structure of 511 large U.S. companies, which were "value-maximizing size," "control potential" and "systematic regulation". They found no significant relationship between corporate governance variables and corporate performance. Based on the performance indicators; return on asset and non-performing loans showed that institutional shareholders in Kenya have no significant influence on financial performance of banks (Barako \& Tower, 2007). This was in sync with the empirical researches in the last decades which shown no significant relationship between board composition and banks performance (Adams \& Mehran, 2008; Romano et al., 2012).

Contrary to this, various studies also found positive relationships between corporate governance and bank performance, director structures and corporate performance as well as corporate performance and financial disclosure. Based on the literature, Grove et al. (2011) pointed out that the extent of competence of the board structure is positively associated with financial performance (investors will long in a portfolio of well governed firms and short in a portfolio of poorly governed firms). A similar study conducted in the Middle East and North Africa shows that there is a positive relationship between corporate governance and bank performance (Enobakhare, 2010).

Therefore the majority of current existing studies showed a positive relationship between corporate governance variables and banks' profitability or efficiency. This highlighted how board size, board composition, board committees and board diversity impact bank performance (De Andres \& Vallelado, 2008). Based on the debate above its worthy while to investigate the impact of corporate governance on banks performance with the focus of the Zimbabwean context.

\section{Research Objective}

The main objective of the study was to:

- To determine whether corporate governance has an impact on commercial banks performance in the Zimbabwean financial sector. 
- To give recommendations to the stakeholders on strategies that can improve corporate governance practices so as to improve the performance of commercial banks in Zimbabwe based on research findings.

\section{Research Hypotheses}

$\mathrm{HO}$ : There is no stationality of data between measures of corporate governance and bank performance?

$\mathrm{H} 1$ : There is a stationality of data between measures of corporate governance and bank performance?

$\mathrm{HO}$ : There is no causal link between corporate governance variables and commercial banks performance.

$\mathrm{H} 2$ : There is a causal link between corporate governance variables and commercial banks performance.

H0: There is no significant relationship between corporate governance practices (board size ratio, board composition ratio, internal board committee's ratio and board diversity ratio) and commercial banks performance.

H3: There is a significant positive relationship between corporate governance practices (board size ratio, board composition ratio, internal board committee`s ratio and board diversity ratio) and commercial banks performance.

\section{Research Methodology}

\subsection{Research strategy, sampling and data collection}

The study employed an exploratory research design which seeks to establish whether or not corporate governance enhances commercial banks performance. The study makes use of the annual board and performance ratios for the period 2009 to 2012. The chosen sample period contained 120 observations from five listed commercial banks (CBZ, FBC, ZB Bank, BancABC and Barclays Bank). Secondary data in the form of bank's financial statements was used.

\subsection{Data analysis}

The study employed descriptive statistics. To test the relationships between the variables, correlations was also utilised in this study. Multiple regression analysis was also used to evaluate and establish a quantitative relationship between multiple dependent and independent variables.

\section{Data Presentation}

\subsection{Descriptive statistics results}

The descriptive statistic results in table 1 below show the mean of $0.153,0.187,10.22,0.630,0.456$ and 0.113 respectively for all variables studied. The results outline that the mean and median are not the same for the entire variables. This implies that the data was not normal distributed around the mean, which might be caused by the techniques used to gather data or the data its self. The ranges of the means found are in conjunction with other studies of board structures (see Patel et al, 2002).

Furthermore, the results show that return on equity, capital adequacy and board committee are positively skewed with a skewness of $0.028,1.31$ and 0.64 respectively and a Kurtosis of skewness of 1.98, 3.45 and 1.96 respectively, which also confirms the fact that the three variables are skewed to the left. Board size, board composition and board diversity have a negative skewenss of $-0.29,-0.33$ and -0.56 respectively and a Kurtosis of $1.25,2.43$ and 2.04 respectively. Based on the Kurtosis it shows that the variables used in the study are not normally distributed as shown by the deviation from symmetry. The Jarque-Bera test, which is joint test of symmetry and mesokurtosis, shows a clear departure from the normal distribution with $0.86,5.92,2.83,0.64,2.29$ and 1.987 between ROE, CA, BS, BC, IBC and $\mathrm{BD}$ respectively. The results of board structure and bank performance are appearing to be heteroskadasticity over time.

Table 1: Descriptive statistics for the period 2009 to 2012

\begin{tabular}{|l|c|c|c|c|c|}
\hline \multicolumn{1}{|c|}{ Variables } & ROE & BS & BC & IBC & BD \\
\hline Mean & 0.152850 & 10.222 & 0.629500 & 0.455800 & 0.112900 \\
\hline Median & 0.155000 & 11.12 & 0.625000 & 0.429000 & 0.12500 \\
\hline Maximum & 0.281000 & 12.5 & 0.750000 & 0.600000 & 0.14300 \\
\hline Minimum & 0.041000 & 0.357000 & 0.462000 & 0.375000 & 0.07700 \\
\hline
\end{tabular}




\begin{tabular}{|l|c|c|c|c|c|}
\hline St.dev & 0.074016 & 0.117562 & 0.086753 & 0.087687 & 0.023337 \\
\hline Skewness & 0.028055 & -0.290526 & -0.332271 & 0.644090 & -0.575183 \\
\hline Kurtosis & 1.984984 & 1.251555 & 2.427982 & 1.956475 & 2.043251 \\
\hline Jarque- Bera & 0.861172 & 2.828900 & 0.640684 & 2.290293 & 1.865607 \\
\hline Probability & 0.650128 & 0.243059 & 0.725901 & 0.318177 & 0.393449 \\
\hline Obser & 20 & 20 & 20 & 20 & 20 \\
\hline
\end{tabular}

\subsection{Inferential statistics: Hypotheses testing}

\subsubsection{Unit Root Test}

To answer the research hypothesis1, unit test was carried out to find if there is non-stationarity in the data under the study, the unit test remove the data lags from individual data. The research used Augmented Dickey Fuller (ADF) unit root tests for data stationarity as shown in table 2 below.

Table 2: Augmented Dicker Fuller Tests

\begin{tabular}{|c|c|c|c|c|}
\hline \multirow{2}{*}{ Variable } & \multicolumn{2}{|c|}{ ADF Stat @ Stationarity } & \multirow{2}{*}{ Order of integration } & \multirow{2}{*}{ Remark } \\
\cline { 2 - 3 } & Intercept & Trend \& Intercept & $\mathrm{I}(0)$ & Stationary \\
\hline ROE & $-6.157464^{\star *}$ & $-5.423244^{*}$ & $\mathrm{I}(1)$ & Stationary \\
\hline BS & $-4.276411^{\star}$ & $-6.506989^{\star}$ & $\mathrm{I}(1)$ & Stationary \\
\hline BC & $-4.158277^{\star}$ & $-4.587830^{\star}$ & $\mathrm{I}(1)$ & Stationary \\
\hline IBC & $-4.011863^{\star}$ & $-6.481585^{\star}$ & $\mathrm{I}(1)$ & Stationary \\
\hline BD & $-4.000395^{\star}$ & $-6.480725^{*}$ & &
\end{tabular}

Note: *, ${ }^{* *}$ and ${ }^{* * *}$ denote $1 \%, 5 \%$ and $10 \%$ level of significance respectively.

The Augmented Dickey-Fuller (ADF) test was used to verify stationary properties of the selected variables. The results show that ROE and CAR data are stationary at $5 \%$ level of significance whereas the data for BS, BC, IBC and BD was all integrated into one unit in order to attain the data stationarity at 0.001 significance level. This implies that ROE and CAR was integrated order zero and $\mathrm{BS}, \mathrm{BC}, \mathrm{IBC}$ and $\mathrm{BD}$ attained stationarity with first differentiation (was integrated of order one). Therefore from the results the entire non-stationary variables were rejected in favour of alternative hypothesis.

\subsubsection{Relationship of variables}

Table 3: Correlation matrix

\begin{tabular}{|l|c|c|c|c|c|}
\hline & $\underline{\text { ROE }}$ & $\underline{\text { BS }}$ & $\underline{\text { BC }}$ & $\underline{\text { BBC }}$ & $\underline{\text { BD }}$ \\
\hline ROE & 1.000000 & & & & \\
\hline CAR & -0.527769 & & & & \\
\hline BS & -0.625546 & 1.000000 & & & \\
\hline BC & -0.416625 & 0.763183 & 1.000000 & & \\
\hline IBC & -0.161714 & 0.623512 & 0.643637 & 1.000000 & \\
\hline BD & 0.007791 & 0.372240 & 0.045000 & 0.178844 & 1.000000 \\
\hline
\end{tabular}

Based on the correlation matrix, results in table 3 above show a significantly negative relationship between return on equity and board size (- 0.625546), this implies that an increase in board size will lead to a decrease in the return on equity and vice versa. There is a relatively positive relationship between return on equity and board diversity (0.007791), this implies that an increase in board diversity will lead to any increase in return on equity and vice versa. A negative relationship between return on equity, capital adequacy ratio and internal board committees $(-0.161714$ and -0.527769 respectively) was also observed, this means that an increase in internal board committees will lead to a decrease in both performance indicators and vice versa.

The observed result between return on equity, capital adequacy and board composition supports the De Andres and Vallelado (2008). The correlation matrix results highlighted seem to be true from a theoretical standpoint; based on the $5 \%$ level of significance, the results are not highly significant and robust, except for board size. We can't concluding 
the results shown, that correlation does not imply causation between variables since there are other factors not considered in the research, this implies that granger causality test should be carried out to support the correlation coefficients of variables.

\subsubsection{Granger Causality Test}

The study used the standard granger causality test to investigate the causal link between corporate governance variables and commercial banks performance, since the variables found should integrated into different order (thus, no cointegration). The granger causality results presented in table 4 below and a pairwise approach applied as well as the test performed against the stated null and alternative hypothesis.

Table 4: Granger Causality Results

\begin{tabular}{|l|c|c|c|}
\hline \multicolumn{1}{|c|}{ Null Hypothesis: } & Obs & F-Statistic & Prob. \\
\hline ROE does not Granger Cause BC & 16 & 2.62487 & 0.1255 \\
\hline BC does not Granger Cause ROE & & 0.77527 & 0.5747 \\
\hline ROE does not Granger Cause BD & 16 & 1.04386 & 0.4407 \\
\hline BD does not Granger Cause ROE & & 0.78584 & 0.5692 \\
\hline ROE does not Granger Cause BS & 16 & 4.44915 & $0.0420^{*}$ \\
\hline IBC does not Granger Cause ROE & & 0.77744 & 0.0336 \\
\hline
\end{tabular}

Note: $(\mathrm{ROE})$ are measures of commercial banks performance; (BS, BC, IBC and BD) are measures of good corporate governance practices in banks.

The Granger causality test verifies the properties of causality between the selected variables. The results show bidirectional causality between ROE, BS and IBC. Therefore, we reject the null hypothesis of absence of causality between board size, board composition and return on equity at $5 \%$ level of significant in favour of the alternative hypothesis, since the reported probability values of 0.0420 and 0.0336 are less than the critical value of $5 \%(0.05)$. This implies that board size and board committees have an impact on commercial bank's performance if the two grown too big (i.e. big board size). However, we accept the null hypothesis of causality between board composition and board diversity, although we do not have enough information to conclude.

The results are also consistent with Ohara and Macey (2003) findings, but contradict Vallelado (2008) who found unidirectional causality between board size and bank performance. The results constitute the main objective of the study, mean that an increase of corporate governance practices enhances commercial banks performance conversely, weak corporate governance practices may result in poor commercial bank performance, bank scandals and consequently commercial bank frauds and this is the case, which is happening in Zimbabwe currently.

\subsubsection{Regression analysis results}

Table 5 below presents the results of the regression analysis, regressing commercial bank performance (dependent variable) against the independent variables, corporate governance practices (board size ratio, board composition ratio, board committees' ratio and board diversity ratio). The model indicates that $87 \%$ ( $R$ Square $=.871$ ) variation in commercial bank performances (BP) is explained by the predictor variables. Furthermore, the model indicated that $83.7 \%$ (adjusted $\mathrm{R}$ squared $=0.837$ ), signify that the model explains of the variations in return on equity indicating a high predictive or explanatory power of the multi regression model employed. The results are in harmony with prior study (Peong \& Devinga, 2010).

The Durbin-Watson indicates that the assumption of independent error is tenable since for this data, the figure is 2.354, which is greater than two, showed that the model was not suffering from autocorrelation so there are no possibility of spurious regression (Durbin \& Watson, 1951). No incidences of multicollinearity are observed in the model since none of the variance inflation factors (VIF) are close to or greater than 5. The analysis of variance table also show that the variables in the model have a statistically significant effect on commercial bank performance ( $F=25.32984$; Sig. $=0.000)$. The results also show that all variables have a statistically significant effect on Bank performance (BP). Statistically significant effects are observed on board size ratio (BS) $(t=3.055$, sig. $=.003)$; board composition ration $(B C)(t=5.625$, sig. = .000); internal board committee ration $(\mathrm{IBC})(\mathrm{t}=2.387$, Sig. $=.020)$ and board diversity ratio $(\mathrm{BD})(\mathrm{t}=1.249$, sig. $=0.021$ ). 
All the four variables (BS, BC, IBC, and $B D$ ) yield positive Beta coefficients indicating that they result in increases in bank performance. Therefore, at $\mathrm{a}=0.05$ level of significance, the study conclude that board size ratio, board composition ratio, internal board committees' ratio and board diversity ratio have a positive effect on bank performance. The model used can depict as follows:

$B P=a+\beta_{1} B S+\beta_{2} B C+\beta_{3} I B C+\beta_{4} B D+E$. banks

Where: $\left(\varepsilon_{t}\right)$ is the error term, $\left(\beta_{i}, \beta_{1}, \beta_{2}, \beta_{3}\right.$ and $\left.\beta_{4}\right)$ are estimation parameters,(i) is the number of commercial

Based on the findings of this study we fail to accept our null hypothesis $(\mathrm{HO})$ that there is no significant relationship between corporate governance practices and bank performance. Therefore this study provides reasonable ground to conclude that corporate governance practices have a positive effect on bank performance.

Table 5: Multiple regression between corporate governance and commercial bank performance

Model Summaryb

\begin{tabular}{|c|c|c|c|c|c|}
\hline Model & $\mathbf{R}$ & $\mathbf{R}$ Square & Adjusted R Square & Std. Error of the Estimate & Durbin-Watson \\
\hline 1 & $.805^{\mathrm{a}}$ & .871045 & .836657 & .152192 & 2.353635 \\
\hline
\end{tabular}

a. Predictors: (Constant), BS, BC, IBC, BD

b. Dependent Variable: Bp

Where: BP- proxy for bank performance (capital adequacy and return on equity), BS - board size ratio,

$\mathrm{BC}$ - board composition ratio, IBC - internal board committee's ratio, BD - board diversity ratio

\begin{tabular}{|c|c|c|c|c|c|c|c|}
\hline \multicolumn{7}{|c|}{ ANOVA $^{a}$} & \\
\hline Model & Sum of Squares & df & \multicolumn{2}{|l|}{ Mean Square } & $\mathbf{F}$ & Sig. & \\
\hline Regression & 97.360 & 10 & 9.736 & \multicolumn{2}{|r|}{25.32984} & $.000^{\mathrm{b}}$ & \\
\hline$1 1 \longdiv { \text { Residual } }$ & 34.743 & 74 & \multirow[t]{2}{*}{.714} & & & & \\
\hline Total & 132.103 & 84 & & & & & \\
\hline \multicolumn{7}{|c|}{ a. Dependent Variable: Bp } & \\
\hline \multicolumn{7}{|c|}{ b. Predictors: (Constant), BS, BC, IBC, BD } & \\
\hline \multicolumn{8}{|c|}{ Coefficients $^{a}$} \\
\hline \multirow{2}{*}{ Model } & \multicolumn{2}{|c|}{ Unstandardized Coefficients } & Standardized Coefficients & \multirow{2}{*}{$t$} & \multirow{2}{*}{ Sig. } & \multicolumn{2}{|c|}{ Collinearity Statistics } \\
\hline & B & Std. Error & Beta & & & Tolerance & VIF \\
\hline (Constant) & .352 & .533 & & .660 & .511 & & \\
\hline BS & .328 & .108 & .303 & 3.055 & .003 & .482 & 2.074 \\
\hline $\mathrm{BC}$ & .641 & .110 & .558 & 5.625 & .000 & .483 & 2.071 \\
\hline IBC & .317 & .129 & .238 & 2.387 & .020 & .479 & 2.089 \\
\hline $\mathrm{BD}$ & .201 & .162 & .165 & 1.249 & .021 & .271 & 3.685 \\
\hline
\end{tabular}

\section{Conclusion}

Corporate governance has an impact on the performance of commercial banks in Zimbabwe, since it helps to restore back investors and depositors confidence, which was eroded out by the recent commercial bank failures. This cannot be emphasised because commercial banks plays a crucial role of intermediary in the economy, through mobilisation of deposits and extension of short-term loans. This section highlighted the conclusions that could be drawn based on the results displayed in chapter four where corporate governance and commercial bank performance was analysed.

\subsection{Does Corporate Governance Impact Commercial Banks Performance in Zimbabwe?}

Based on the multi regression results and the granger test results with this sufficient evidence we conclude that the corporate governance has an impact on commercial banks performance in Zimbabwe, although we don't have enough information to totally conclude the hypothesis. The regression results show that bank performance depend on the level of corporate governance practices. However, board committee show that the banks must have an optimal number of committees in order to perform well. The board diversity has shown a positive impact on the commercial bank 
performance holding macroeconomic condition constant. The Zimbabwean commercial banks have not been performing for a long time due to the continued deterioration of the good corporate governance practices. This is negatively impact on the commercial banks performance, leading to bank failures as witnessed recently.

\subsection{The Key Characteristics of Corporate Governance}

The results have shown strong interdependence between board size, board composition, board committees and board diversity through a regression, correlation matrix and granger causality for all variables. It is apparent that board size and board committees are crucial for commercial bank's performance since any change of the two-impact bank profitability more than the other two, board composition and board diversity. The findings present sufficient evidence to conclude that board size, board composition, board committees and board diversity are the key characteristics of corporate governance since they explain much of the variation in bank performance in Zimbabwean commercial banks.

\subsection{Relationship between Corporate Governance and Bank Performance}

The regression results have shown a positive relationship between board composition and board diversity with commercial bank's performance, although board size and board committees have a negative relationship with performance. However, board size and board composition has a positive relationship with capital adequacy ratio. Despite board committee which have both negative relationships with two performance indicators, there is enough evidence to conclude that corporate governance has a positive relationship with commercial banks in Zimbabwe.

\subsection{Improvements in Corporate Governance practices}

The regression results have shown that board composition and board diversity has a significant positive relationship with commercial banks performance in Zimbabwe. This implies that commercial banks should increase the number of independent non-executive directors as well as women directors into the board of directors so as to harness the commercial bank's profitability. Apart from this the board of directors should find the optimal board size as well as the optimal board committees, since the regression results shows that they have a significant negative relationship with commercial banks performance. This means that the bank should have number of directors, which make it to be profitable. Although a big board size and board composition has a positive relationship with the commercial bank's capital adequacy ratio. As a conclusion the commercial banks in Zimbabwe must chose an optimal number of directors composed of more independent non-executive directors and women directors so as to enhance performance.

\section{Recommendations}

\subsection{To Commercial Banks}

i. Optimal directors:

There is need commercial banks to have an optimal board size and board committee so as to increase performance. There is also a need to increase the board composition and board diversity so as to enhance investor's confidence with the bank due to increase of independency of the board.

ii. Compliance with Regulation:

There is need for commercial banks to comply with corporate governance requirements and best practises so as to avoid bank closure and placement under judicial management. Bank closure would tend to reduce the number of commercial banks on the financial market which will induce some financial volatility.

\subsection{To Government}

i. National Corporate Governance Policy:

Government should come up with the national corporate governance policy, which will make governance equality among commercial banks in the country. Since without such a policy framework, monitoring and assessment of commercial banks corporate governance will be limited to only in-house organisational appraisals. In addition, this would help regulators to enforce bank regulation and supervision on an equal platform to all commercial banks. 
ii. Macroeconomic Stability:

The government needs to work towards stabilising the macroeconomic situation (liquidity crunch in the country) so as to increase commercial banks performance. When the economic fundamentals are not addressed, commercial banks failure will continue, since banks will continue do unethical practices in order to survive. Stability of the macro economy will also increase corporate governance, which would induce an incentive for commercial banks to perform.

\subsection{To Investors}

Investors with a profit motive should target banks with good corporate governance practices. This is believed that by intuition, formulation and implementation of complimentary good corporate governance practices and performance growth policies this would lead to achievement of the oral objective of the bank, shareholder wealth maximization which is needed by investors.

\subsection{To The Reserve Bank of Zimbabwe (RBZ)}

i. There is a need for the RBZ to enforce corporate governance practices in the commercial banks, separation of ownership and control (say no one can be a major shareholder, board chairperson and CEO) so as to enhance bank performance. This helps to ensure that the director's chairperson or CEOs do not become too strong, which will then adversely affect the bank independency and transparency through the decision making that supports their interests.

ii. There is need for the RBZ to increase the bank supervision and regulation on the commercial banks so as to enhance banking safety and sustainability. This will also serve to improve the competency of the commercial banks in the financial market.

\subsection{To The Directors}

i. Improving the Fiduciary Duties:

The directors should practice due care and diligence on their undertakings. The directors are also mandated by the company act to be responsible and accountability. The directors should disclose up all their activities to the public through audited financial statements. This would help the bank to attract and return its customers and investors if directors practice their duties in an ethical way.

ii. The Need to Address Issues of Board Structure:

There is a need for directors to address issues of board structure in order to avoid a large chunk of directors in the commercial bank board. The board structure as shown by the regression should have more independent non-executive directors. This would tend to attract more potential investors since investors favour a bank with more independent non-executive directors than executive directors.

\section{Suggestions for Further Research}

While tests on the corporate governance continue, the final outcome of the raging debate will be a compromise between competing schools of thought. The researchers found it important for further research to adopting a multidisciplinary approach that incorporates both the qualitative and quantitative research tools. This would help to explore further about the impact of board structure on commercial banks or non-banking institutes if the samples size chosen is big enough. There is also need to research about the impact of ownership structures on the commercial banks in Zimbabwe. Finally, all results based on the assumption that there is strict exogeneity among the independent variables and this hypothesis could not verified.

\section{References}

Adams, R., Hermalin, B. E., \& Weisbach, M. S. (2008). The role of boards of directors in corporate governance: A conceptual framework and survey (No. w14486). National Bureau of Economic Research.

Adams, R. A. (2012). Governance and the Financial Crisis. International Review of Finance, 12(1),7-38.

Adams, R. B., \& Mehran, H. (2008). Corporate performance, board structure and their determinants in the banking industry. Federal 
Reserve Bank of NY Staff Report 62(330), Revised October 2011.

Adams, R. B., \& Ferreira, D. (2009). Women in the boardroom and their impact on governance and performance. Journal of financial economics, 94(2), 291-309.

Ahmad, S. (2006). Corporate Governance and Performance of Commercial Banks in Pakistan. In forth coming 23 rd Symposium on Money, Banking and Finance, Lille, France.

Alkdai, H. K. H. \& Hanefah, M. M. (2012). Audit committee characteristics and earnings management in Malaysian Shariah-compliant companie. Business and Management Review, 2(2), 52- 61.

Bank of Italy. (2008). Supervisory Provisions Concerning Banks' Organization and Corporate Governance. March, 2008.

Barako, D. G. \& Tower, G. (2007). Corporate governance and bank performance: Does ownership matter? Evidence from Kenyan banking sector, 10(2), 43-79.

Bhagat, S., \& Bolton, B. (2008). Corporate governance and firm performance. Journal of Corporate Finance, 14(3), $257-273$.

Blair, M. (1995). "Ownership and Control: Rethinking Corporate Governance for the Twenty First Century". Brookings: Washington.

Boone, A. L., Casares Field, L., Karpoff, J. M., \& Raheja, C. G. (2007). The determinants of corporate board size and composition: An empirical analysis. Journal of Financial Economics, 85(1), 66-101.

Busch, A. (2008). Banking regulation and globalization. Oxford University Press.

Bussoli, C. (2013). 3 Corporate governance and bank performance in Italy. Financial Systems in Troubled Waters: Information, Strategies, and Governance to Enhance Performances in Risky Times, 40.

Busta, I. (2007), Board effectiveness and the impact of the legal family in the European banking industry. FMA European Conference, Barcelona-Spain.

Calabrese, A., Costa, R., Menichini, T., Rosati, F., \& Sanfelice, G. (2013). Turning Corporate Social Responsibility-driven Opportunities in Competitive Advantages: a Two-dimensional Model. Knowledge and Process Management, 20(1), 50-58.

Caprio, G., Laeven, L., \& Levine, R. (2007). Governance and bank valuation. Journal of Financial Intermediation, 16(4), $584-617$.

Chiorazzo, V., Milani, C. \& Salvini, F, (2008). Income Diversification and Bank Performance: Evidence Italian Banks. Journal of Financial Services, 33(4), 181-203.

Coleman, K. (2008). Corporate governance and firm performance in Africa: A dynamic panel data analysis. Studies in Economics and Econometrics, 19(2), 350-367.

Cornett, M. M., McNutt, J. J., \& Tehranian, H. (2009). Corporate governance and earnings management at large U.S. bank holding companies. Journal of Corporate Finance, 15(5), 412-430.

De Andres, P., \& Vallelado, E. (2008). Corporate governance in banking: the role of the board of directors. Journal of Banking and Finance, 32(9), 2570-2580.

Denis, D. K., \& McConnell, J. J. (2003). International corporate governance. Journal of Financial and Quantitative Analysis, 38(01), 1-36.

Dutta, P., \& Bose, S. (2007). Gender diversity in the boardroom and financial performance of commercial banks: Evidence from Bangladesh.

Enobakhare, A. (2010). Corporate governance and bank performance in Nigeria. Diss. Stellenbosch: University of Stellenbosch.

Farber, D. B. (2005). Restoring trust after fraud: does corporate governance matter? The Accounting Review, 80(2), 539-561.

Fernando, A. C. (2009). Corporate governance: Principles, policies and practices. Pearson Education India.

Franks, J. \& Mayer, C. (2000). Ownership and control of German Corporations. Review of Financial Studies. Social Science Electronic Publishing, Inc.

Grove, H., Patelli, L., Victoravich, L. \& Xu, P. (2011). Corporate Governance and Performance in the Wake of the Financial Crisis: Evidence from US Commercial Banks, Corporate Governance: An International Review, 19(5), 418-436.

Huse, M. (2005). Accountability and creating accountability: a framework for exploring behavioral perspectives of corporate governance. British Journal of Management, 6(4), 65-79.

International Finance Corporation. (2004). "The Russia Corporate Governance Manual: Corporate Governance Introduced". Alpina Business Books, Moscow.

Inyang, B. (2009). Nurturing corporate governance system: The Emerging Trends in Nigeria. Journal of Business Systems, Governance and Ethics, 4(1), 2.

Jensen, M. (1993). The Modern Industrial Revolution, Exit, and the Failure of Internal Control Systems. Journal of Finance, 48(5), 831880.

Jensen, M. (2001). Value maximisation, stakeholder theory, and the corporate objective function. European Financial Management, 7(3), 297-317.

Kang, J. K., \& Shivdasani, A. (1995). Firm performance, corporate governance, and top executive turnover in Japan. Journal of financial economics, 38(1), 29-58.

King II, (2002). Executive summary of the King committee on corporate governance. March 74 (2002).

Kolk, A., \& Pinkse, J. (2010). The integration of corporate governance in corporate social responsibility disclosures. Corporate Social Responsibility and Environmental Management, 17(1), 15-26.

Laeven, L., \& Levine, R. (2009). Bank governance, regulation and risk taking. Journal of Financial Economics, 93(2), $259-275$.

Lin, X., \& Tang, Q. (2008). The roles, responsibilities and characteristics of audit committee in China. Accounting, Auditing \& Accountability Journal, 21(5), 721-751.

Najjar, B. (2011). The Determinants of Audit Committee Independence and Activity: Evidence from the UK. International Journal of Auditing, 15(8), 191-203. 
OECD, (2004). African Economic Outlook: Zimbabwe. AfDB/

Ogbechie, C., \& Koufopoulos, D, N. (2007). "Corporate Governance Practices in Publicly Quoted Companies in Nigeria" presented at the 4th World Congress on Corporate Governance jointly sponsored by the Management of Innovation and New Technology (MINT) Research Centre, the Directors College and the DeGroote School of Business, McMaster University, Hamilton, Ontario, Canada, January 24-26.

Ohara, M., \& Macey, J. R. (2003). Corporate governance of banks. Economic Policy Review, 9.

Patel, S, Balic, A., \& Bwakira, L. (2002). Measuring Transparency and Disclosure at Firm-Level in Emerging Markets. Emerging Markets Review, 3 (2002), 325-337.

Reserve Bank of Zimbabwe, (2012). Monetary Policy Statement, Issued in terms of the Reserve Bank of Zimbabwe. Act Chapter $22: 15$ Section 46.

Ramano, G., Ferretti, P. \& Quirici, M. C. (2012).Corporate Governance and Efficiency of Italian Bank Holding Companies during the financial crisis: an empirical analysis, in Mizuno, M., Pizzo, M. and Kostyuk, A. (Eds), "Evolution of corporate governance in banks", Virtusinterpress. Sumy, 98(2012), 128-140.

Shelash Al-Hawary, S. I. (2011). The Effect of Banks Governance on Banking Performance of The Jordanian Commercial Banks: Tobin's Q Model "An Applied Study". International Research Journal of Finance and Economics, 71(5), 34-47.

Shrader, C. B., Blackburn, V. L. \& Iles, P. (1997). Women in Management and Firm Financial Value: An Exploratory Study. Journal of Management Issues, 9(1997), 355-372.

Sierra, G., Talmor, E., \& Wallace, J. (2006). Examination of multiple governance forces within banking holding companies. Journal of Financial Services, 29(2), 105-123.

Staikouras, P., Staikouras, C. \& Agoraki, M. E. (2007). The effect of board size and composition on European bank performance, European Journal of Law and Economics, 23(1), 1-27.

Strine Jr, L. E. (2010). One Fundamental Corporate Governance Question We Face: Can Corporations Be Managed for the Long Term Unless Their Powerful Electorates Also Act and Think Long Term? Business Lawyer, 66(1).

Trabelsi, M. A. (2010). Governance and Performance of Tunisian Banks. International Journal of Economics and Finance, 2(3), $189-198$.

Uzun, H., Szewczyk, S. H. \& Varma, R. (2004). "Board composition and corporate fraud". Financial Analysts Journal, 60(3), 33-43.

Vaithilingam, S. Mahendhiran, N., \& Muthi, S. (2006). Key drivers for soundness of the banking sector: lessons for developing countries. Journal of global business and technology, 2(1), 114-144, 163.

Vance, S. C. (1978). Corporate governance: assessing corporate performance by boardroom attributes. Journal of Business Research, 6(3), 203-220.

Williams, S. M. (2002). Board of Director Determinants of Voluntary Audit Committee Disclosures: Evidence From Singapore, Corporate Governance and Intellectual Capital Archive Research Paper, Singapore Management University,7(11), 5976-89.

Yakasai, G. A. (2001). Corporate governance in third world country. With particular reference to Nigeria. Corporate governance, 9(3), 238-253.

Zaharia, C., Tudorescu, N., \& Aharia, I. (2010). How bad governance practices inflicted systemic risks on the global economy. Economics, Management \& Financial Markets, 5(1).

Zahra, S. A. \& Stanton, W.W. (1988). The Implications of Board of Directors Composition for commercial banks. Strategic management, 12(1988), 135-153.

Zulkafli, A. H., \& Samad, F. A. (2007). Corporate Governance and Performance of Banking Firms: Evidence from Asian Emerging Markets. Issues in Corporate Governance and Finance Advances in Financial Economics, 12(1, 49-74. 